\title{
Terraforma. Un musubi per lo Stretto disegnato
}

Rosario Giovanni Brandolino

\section{Abstract}

Il contenuto descrive il processo di elaborazione e le analogie di espressione di un logo dovute a una complessità di estensione dell'immagine. Segno immateriale sulla soglia di una raccolta dati di derivazione, proposta come natura di una descrizione, che contiene forme, testi e umori di una dimensione globale.

Una proposizione sintetica del - connettere - che si avvale dei nodi di una disciplina orientale che pone in essere la contemporaneità di un filo blu-mediterraneo con le terre d'Oriente, nella corrispondenza di una tessera d'intersezione.

\section{Parole chiave}

logo, disegno, immagine, nodo, Stretto.

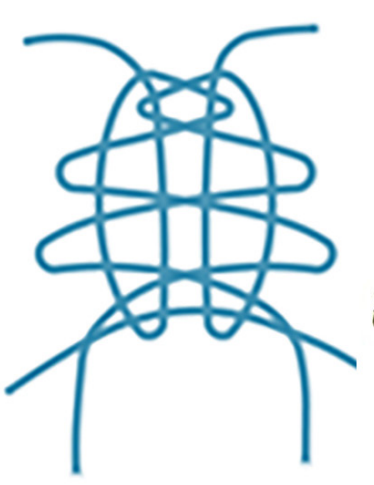

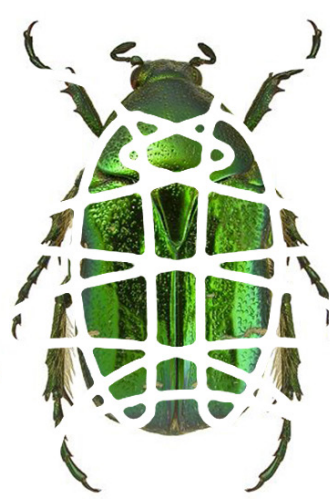

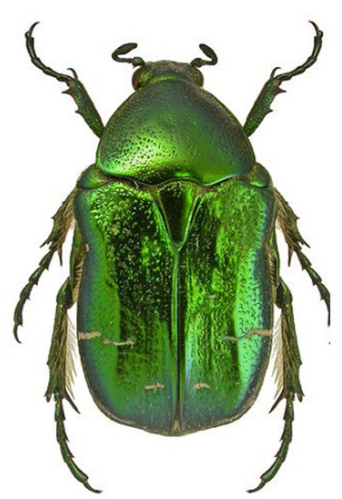

doi.org// 0.3280/oa-548.165 
"ll disegno è una forma di meditazione, ti costringe a fare attenzione che è la ragione ultima del fare arte"

[Milton Glaser, grafico e illustratore]

Fig. I. Musubi.

L'ideogramma de

termine musubi,

ovvero 結, è composto

dai due termini ito 糸,

cioè 'filo', e yoshi 吉, cioè

'felicità'. Il musubi lega due legame con la natura.
Fig. 2. Appunti di studio, nodo tra connessione e identità.
Il brandmark di una connessione è il carattere identitario che pone l'immediatezza di una immagine con la sintesi del suo aspetto coordinato di semplicità, riconoscibilità e immediatezza.

Un collegamento, per una duplice unione fra più cose, tra iconosfere [I] e visual identity. L'idea che si sottopone è il concetto o un qualcosa di fissato per un istante che s'identifica nella memoria acquatica di un non ricordare nulla, ricordare qualcosa, ricordare tutto.

Un insieme di segni che si riflette su di una solcatura ondosa di uno spartiacque che divide il Fretum Siculum [2] di un ordine fluttuante.

Tra i riferimenti stabiliti, nell'astrazione concettuale, vi è un capovolgimento d'immagine in un riflesso che intreccia lo sguardo di visioni dove la pianura liquida include sia il tracciato della schiuma che solleva un remo, sia il solco del tracciato da un'elica, dinanzi all'acqua che ritorna.

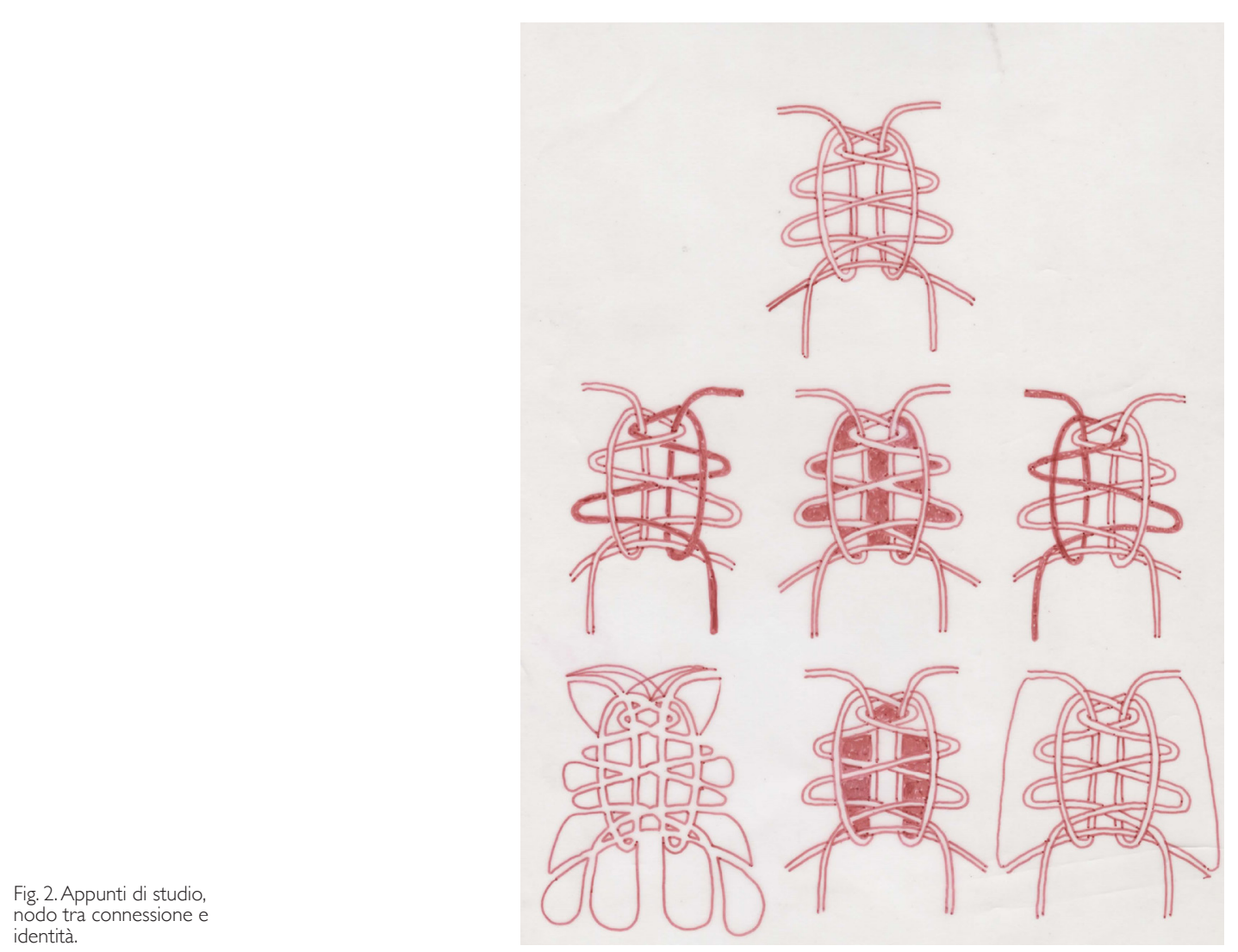



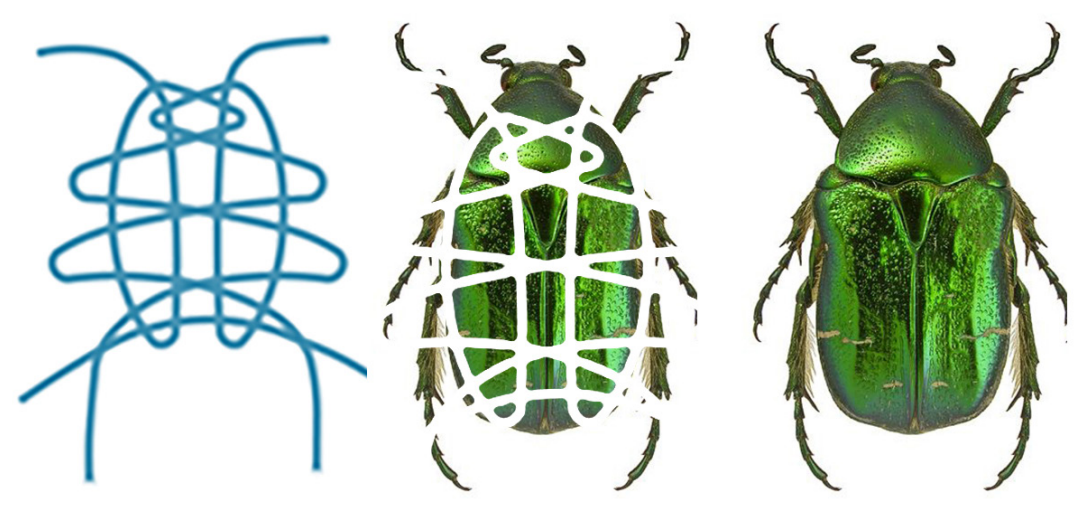

L'immagine si avvale di una lettura astratta in cui si costruisce il segno di un momentaneo passaggio, con implicazioni idrodinamiche, dove si tracciano alcune liquide impronte di un moto ondoso che si conclude con l'ossessione di incoronare qualcosa che non esiste: un canale fluido tra le soglie di un paradosso velato.

"Dalla terra con occhi sognanti guardiamo il mare e quando siamo in mare guardiamo la terra come un sogno", in questa duplice assonanza di Fausto Melotti [3], si ritrovano i segni che aprono il vagare delle vele a tutti i venti.

Una rotta tra due terre che include riflessioni, ricordi e considerazioni formali per far respirare un vuoto, tra la seduzione della memoria e il contagio dei sentimenti.

Una tensione continua e invisibile di un roteare che nel navigare ritrova il segno in una ideale e stabile visione.

La rappresentazione è andare verso le cose di un circolare sistema di un consueto roteare, un movimento meccanico da porto in porto, da regione a regione.

L'elemento che emerge è un vicendevole transito tra due soglie di terraferma che graffiano la superficie con righe originate da un usuale itinerario.

Un luogo fluido che diviene una composizione di segni che offre la possibilità di organizzare le informazioni e veicolare i significati.

La visione dello Stretto, tra bastardi, garofoli e macchie d'olio, stabilisce un rapporto di transito del traghettare che omette i segni invisibili di continui scorrimenti ed ormeggi su linee d'acqua.

Le connessioni che si trasmettono tra vie d'acqua e comandi acustici rappresentano una impalpabile comunicazione di interferenze, tra scie di navigazione e segnali di bordo.
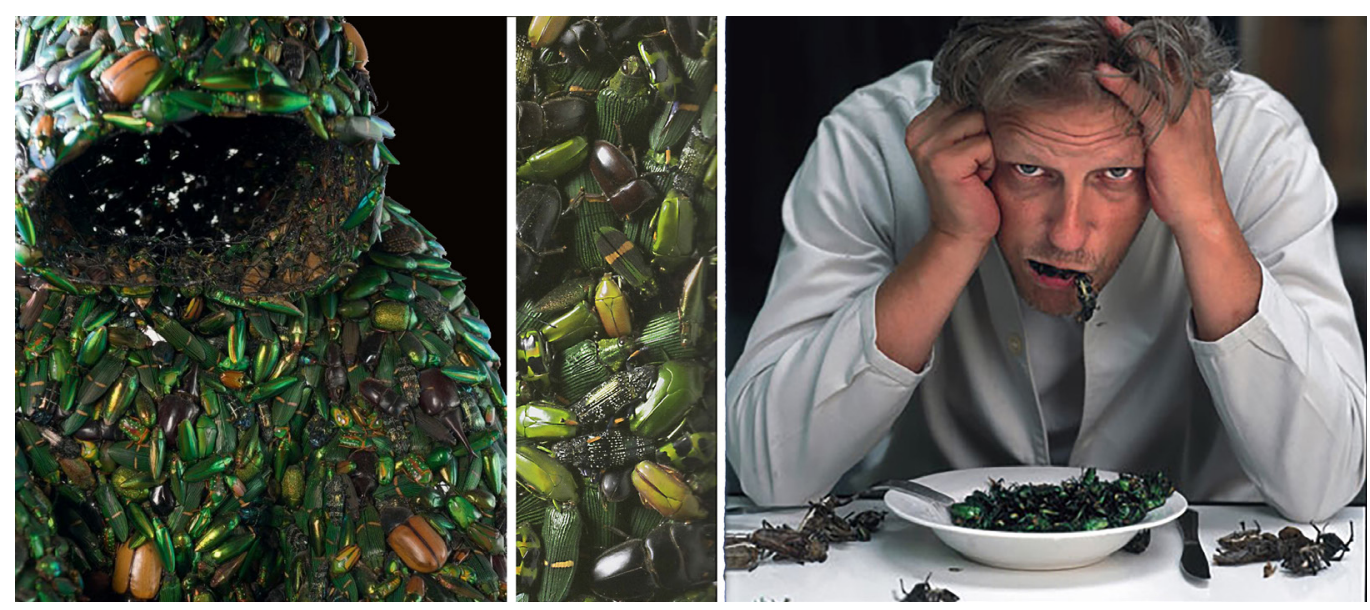
Fig. 5. Nicola Tripodi, Penelope e il filo di Arianna, 2019

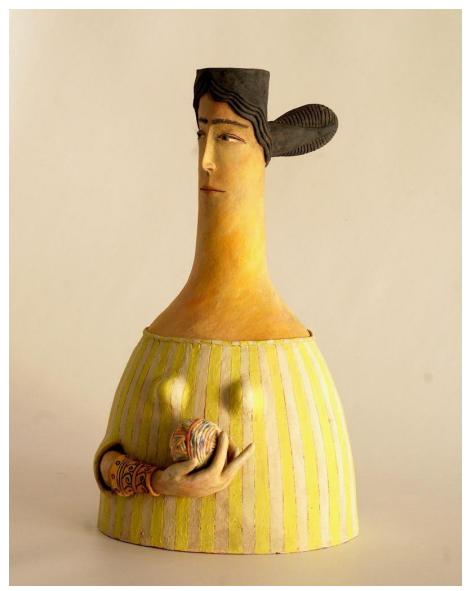

L'idea che appare è un segno che si affaccia sul cammino di un filo, siero greco di linee e trame di un mito femminile che, tra tela di Penelope [4] e il gomitolo di Arianna [5], rivelano una connessione immateriale per un apparente transizione del navigare tra raccordi e intrecci.

Tra doppi sensi, ambiguità e interpretazioni multiple di un filo vi è il raccordo che rivela la continuità di una percezione da donare a Teseo che tra lo smarrimento di un dedalo rileva l'uscita e l'astuzia di Arianna.

"Venga dunque ogni Teseo al nostro Labirinto

senza temere del Minotauro e degli errori

perché il filo della sua Arianna, gli servirà da guida

la più sicura che mai desiderare si possa,

senza di cui è vana ogni opera,

gettata al vento ogni fatica"

La tela di Penelope, invece, rileva il tessere di un interminabile un transito che, nel rintracciare la trama logica attende il rientro di Odisseo, tra le distanze e le coordinate assolute che si esprimono in base ad una struttura tessile di una non finita visione.

"Tela sottile, tela grande, immensa,

A oprar si mise [...]

$[\ldots]$ Intanto,

Finché il giorno splendea, tessea la tela

Superba; e poi la distessea la notte

Al complice chiaror di mute faci"

Il disegno del logo annota l'astrazione di un luogo, parte di un ricamo tra le sponde, un'orditura affiorante seguendo gli allineamenti di un carambolare, simile a uno scorrimento di biglie su un piano liscio [6].

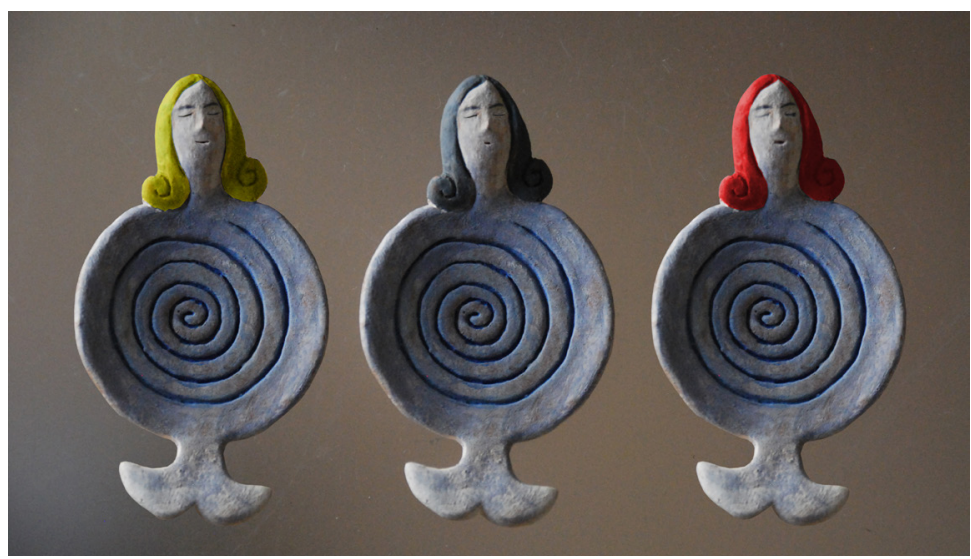


Altri indirizzi di lettura del contorno si possono riconoscere nella forma di una cetonia aurata [7], che riconsegna la forma dell'insetto alla reminiscenza tra le Nuvole di Aristofane [8] e le opere di Jan Fabre [9]. E, successivamente, ad una variabile elasticità di uno stay, una forma di allacciamento per raccordare o allontanare un tessuto intorno al seno, come si trae da una rappresentazione cretese, del 2000 a.C., della dea serpente [10].

Segni di fortuna o di elasticità allusiva rappresentano la variazione di distanze di mediterranei invisibili per abbordare, sulla diversità urbana, un dialogo circolare nello Stretto.

Sono metafore di un equilibrio nascosto nel fascino ingannevole delle sirene [II]. Un rimando all'Area dello Stretto, dove sono scritte diverse connessioni oniriche sulle linee d'acqua narrate da Omero a Stefano D'Arrigo nel corso del tempo.

Ma, come afferma Georges Simenon, "Oltre Messina, a dispetto della Grecia, è già un'altra cosa, è il Mediterraneo avanti Cristo, è l'Oriente..." [12] ed è ciò che si avverte nel disegno di un nodo musubi.

II musubi dello Stretto disegnato, forse, nasconde un suggerimento in un verso di Roberta Joan Anderson: "Eccoti una conchiglia, dentro ci sentirai un sospiro..." [13].

Sul suggerimento di un verso, forse, si avverte il dialogo per un invisibile intreccio da annodare.

Remake, escamotage e allusione sono parametri di necessità per conferire all'immagine un segno che tra le direzioni osservate può contenere un codice di transizione tra l'aspetto fisico e la sua anima.

Sul movimento di un continuo mediterraneo, con la descrizione di correnti, coste, fondali, maree, segnali, venti si rivelano invisibili traiettorie e temporanee scie su una superficie liquida di un sospeso e allusivo incorporeo navigare.

Nel connettersi con i luoghi l'elemento grafico del comunicare che si ritrae rappresenta un modo per sintetizzare tensioni di appartenenza. L'immagine mediata dello Stretto, tra l'isola e la penisola, delinea lo scorrimento del navigare su una sequenza direzionale con linee di spedizione opposte.

Così come Jorge Francisco Isidoro Borges Acevedo, in Finzioni del 1944, definiva un'assenza di logica l'incapacità di concettualizzazione che porta el memorioso vi è la necessità a costruire un sistema singolare nel comporre una traccia analoga per un'identità sospesa, così come "Funes ricordava non solo ogni foglia di ogni albero di ogni bosco, ma ognuna delle volte che l'aveva percepita o immaginata" [14].

Fig. 7. Tanaka lkko, Kamigatagei no kai, 1973 (Lincontro delle arti del lo spettacolo.

Fig. 8. Tanaka lkko, Music today ' 80,1980 Manifesto per spettacolo.

Fig. 9. Tanaka Ikko, Music today '85, 1985 Manifesto per lo spettacolo.
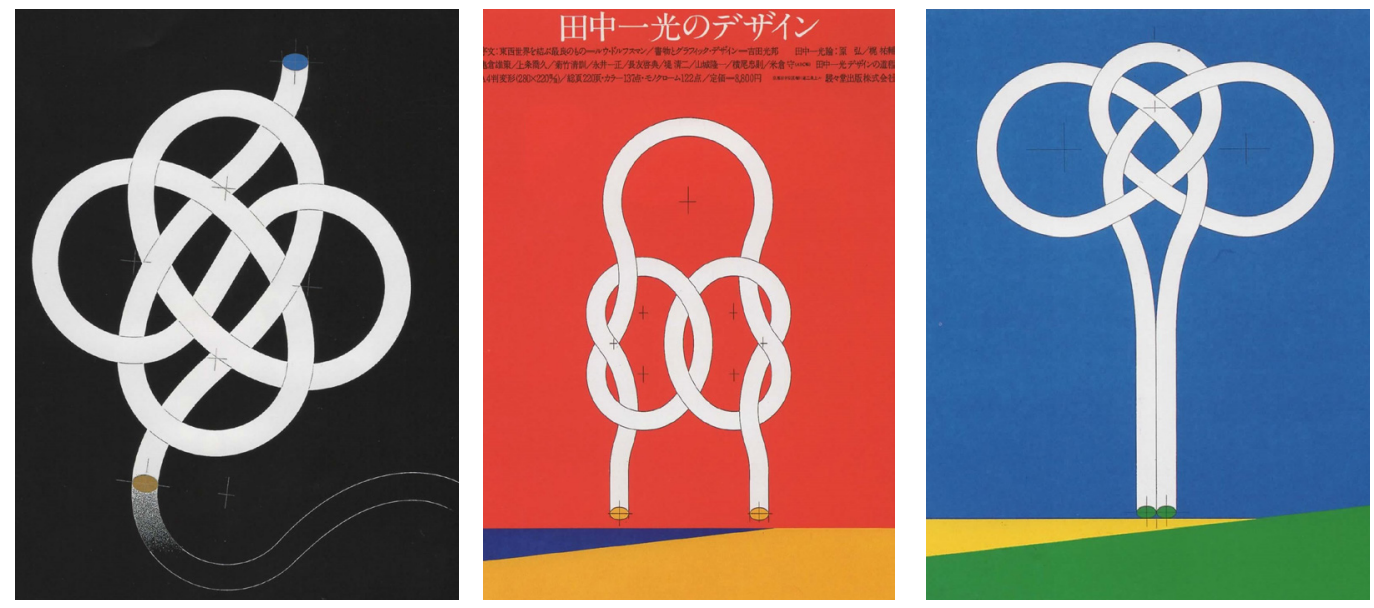

Il disegno di 'Terraforma' contiene la memoria di una traversata nel suggerimento di un profluvio. Una analogia che, in una antica stampa orientale giapponese, rielabora lo schema di un nodo musubi. 
Nella lingua nipponica non esiste un solo punto che esprime una nozione di nodo ma vi sono quattro situazioni che delineano delle diverse esteriorità:

- musubi, raffigura ciò che connette

- yui, esprime ciò che lega

- me, ritrae un vuoto che viene chiuso

- shime, delinea un indicatore della chiusura.

Tale complessità è equivalente all'importanza che il nodo riveste nella cultura giapponese [I5].

II nodo musubi è il vecchio modo con cui si chiamava il Dio locale ... questa parola ha un significato profondo con i poteri della divinità e le corde intrecciate sono una delle forme del Dio stesso e rappresentano il flusso del tempo.

"Unire i fili insieme è 'musubi',

connettere le persone insieme è 'musubi',

lo scorrere del tempo è 'musubi'.

Le note che insieme compongono una melodia è 'musubi'.

'Musubi' sono i fili del tempo e del destino, che si intrecciano, si torcono, si sciolgono e a volte tornano ad intrecciarsi ... questo è musubi ... questo è il tempo" [16].

Altre considerazioni di un rapporto sul connettere nodale sono le indicazioni che emergono dagli allacciamenti di Tanaka Ikko [I7], sono immagine, interrelazione, stilemi e testimonianze di un mondo fluttuante, segni del superfluo nell'arte della semplificazione.
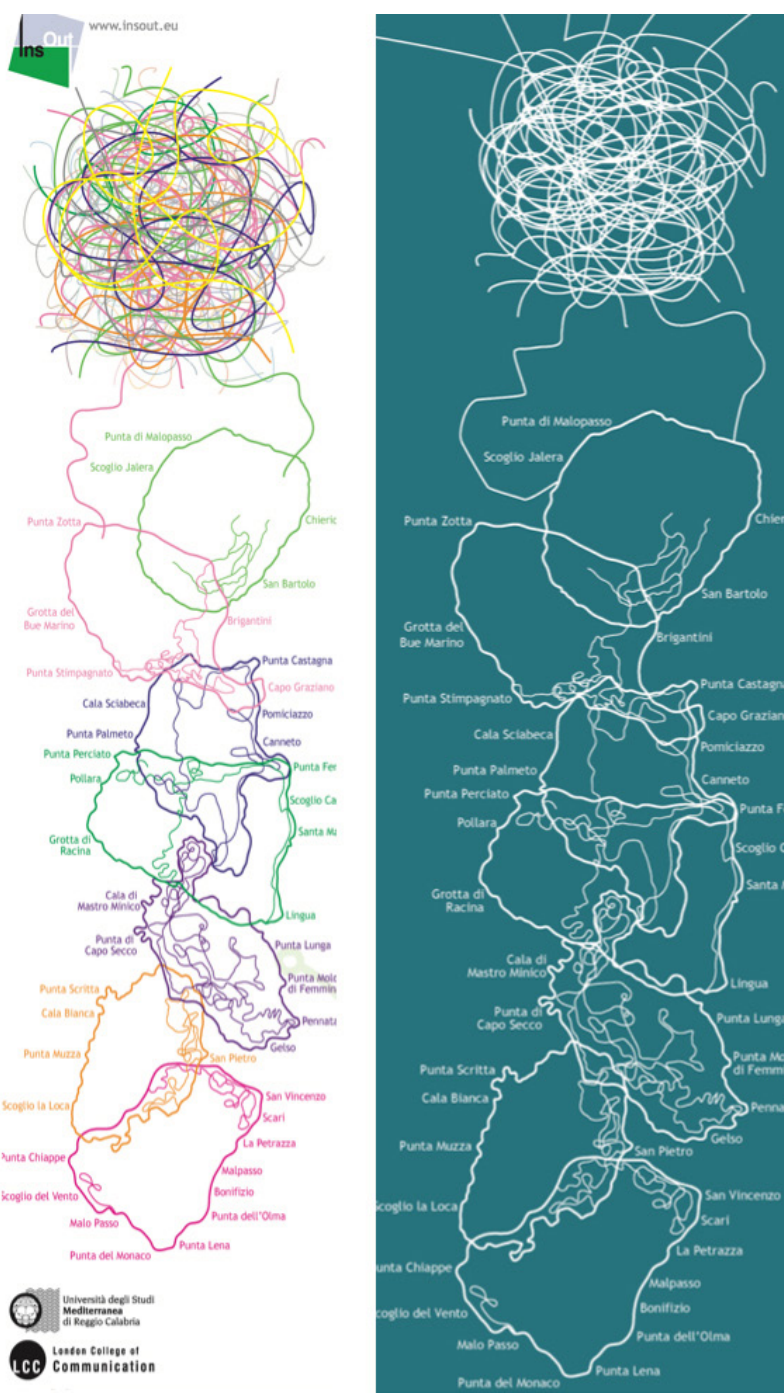
Altre linee tracciate, si ritrovano su differenti esperienze con analogie similari, una risacca contemplativa e un senso formale che raccoglie riflessioni su delle composizioni in ambiti diversificati per un concetto di sintesi.

Ostacoli di una comunicazione di una stagione con diverse esperienze trattano, un ripetere senza monotonia, un programma di comunicazione integrata dell'arcipelago eoliano [18]. II logo, anch'esso filiforme, propone una riflessione critica per promuovere l'immagine di un laboratorio creativo tra due istituzioni - Università Mediterranea e London College of Communication - per un branding delle sette isole.

II branding realizzato riguarda l'estensione di una forma filiforme che tende a definire un significativo coexist di un ambiente trans-ipogeo, percorso talpa riguardante l'iconica tube map londinese disegnata da David Shrigley [19] nel 2006, e la proiezione di un brisè sulle terre d'acqua nelle isole Eolie.

Mescolanze nella visione di un linguaggio per decrittare il context, tra una magia organica e una onirica, prende in considerazione delle linee colorate e le ripone come un semplice caotico scarabocchio.

Una dimensione che appartiene all'intuito dell'osservare che similmente si sviluppa dentro un'immagine dei Guns N' Roses [20], in Spaghetti incident? del 1993, che fa parte del collegamento figurativo di uno scatto.

Altri fili sospesi riguardano il logo per la Casa dell'Architettura della Città Metropolitana di Reggio Calabria [2I], su una iniziativa coordinata con la città di Porto. L'immagine trae origine da un frammento dello Zibaldone leopardiano (256, I ottobre 1820) che, nel duecentennale di una scrittura, si affida ad un pensiero filosofico e filologico che diviene immagine, contenuto e forma.

La costruzione di uno spazio sospeso che riporta i versi di 'casa pensile in aria sospesa con funi a una stella' [22], rammentando che le Case contengono storie e le Storie contengono universi.

Una costruzione identitaria, dunque, che si connette ancora con le ambiguità percettive dell'arte in alcune osservazioni di Ruth Asawa [23] quando afferma che "la frugalità di una linea, crea qualcosa nello spazio, racchiudendolo senza occluderlo" e di altri artisti come Kue King [24] che "modella il filo usando una tecnica di intreccio additivo" e di Chiharu Shiota [25] che intreccia un ordito di fili e "chiama in causa la connessione che sente con la natura".
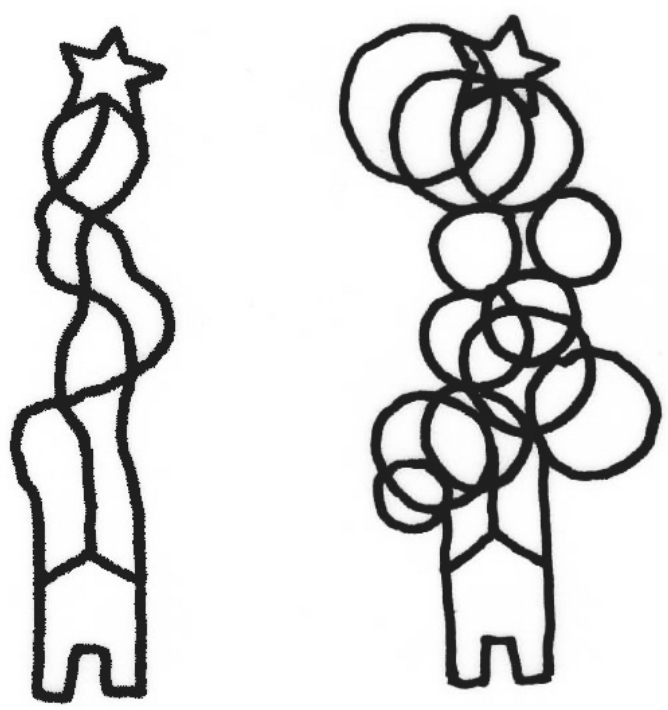
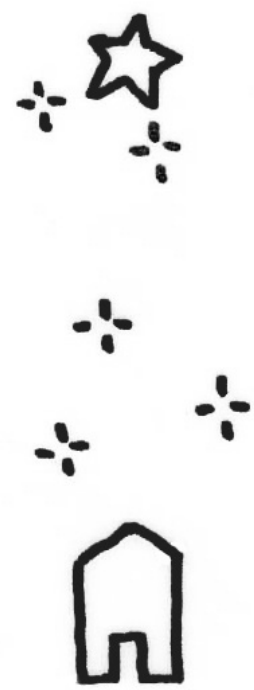


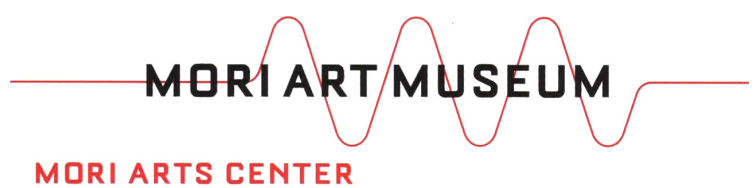

MORI ARTS CENTER
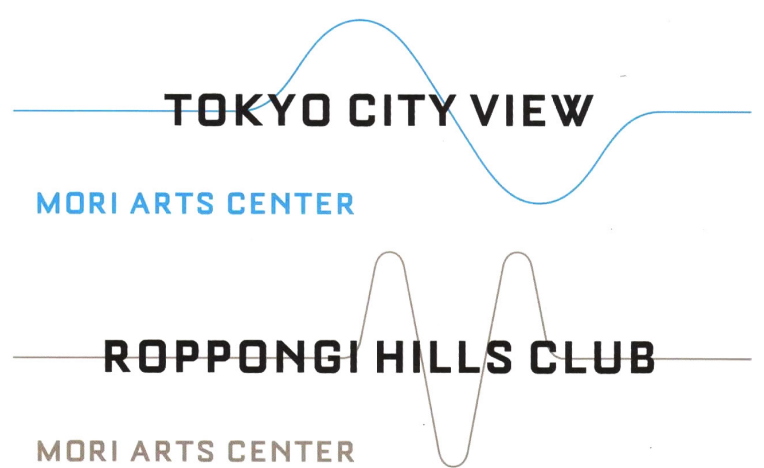

RQPPQNGI ACADEMY HILLS MORI ARTS CENTER

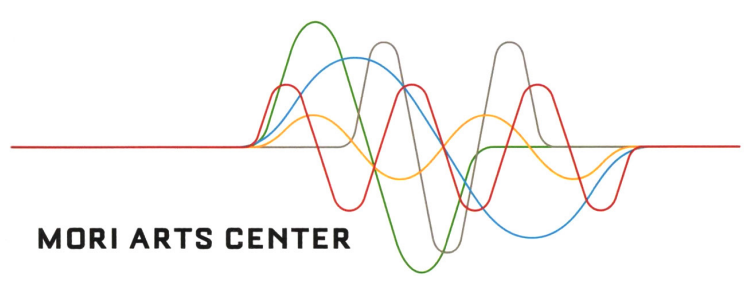

Il logo realizzato per Connettere è un disegno per annodare e tessere, definisce una intersezione di influenze per ricomporre un corporate identity per lo Stretto disegnato. Un intreccio di forme lineari che rappresenta il topos di un doppio, due linee autonome di entità separate nell'incrocio di un insieme di nodi che attraversano due mari.

Un mondo segreto sotto il pavimento [26] liquido che sulla linea del Cenide, in greco Kainis, ricompone l'asse ortogonale di una morfologia sommersa tra i due mari.

Nell'identità del mito di Cenis [27] vi è una similitudine cangiante che esprime un vicendevole attraversamento che appare nella figura del corpo [28] e nel mutamento di una ninfa. Il logo rappresenta il nodo di una connessione sulle linee di un tragitto tra i versanti di un intermezzo mediterraneo, tra il canale del Bosforo e lo Stretto di Gibilterra, e la distanza tra due terre.

L'espressione del logo 'Terraforma' contiene la lettura di un aspetto formale che ha come predecessori il plurifilo di David Shrigley, per la Tube Map di Londra nel 2006, il pentafilo di Johnatan Barnbrook per il Mori Artis Center di Tokyo nel 2004 e il doppio filo di un antico musabi giapponese che rappresenta un biunivoco trend di navigatori e naviganti in una connessione fluttuante sotto un cielo sfibrato. 
Fig. 13. AquaSonic, una 'seapunk' band danese, fonde da canto e musica da camera per produrre una performance onirica su uno spazio liquido. Laila Skovmand, come una sirena, esprime un canto accattivante (Credit images: Ph. Jamie Simpson @ Herald and Times Group / Ph. Charlotta De Miranda in https://style. corriere.it/... / Aquasonic www.betweenmusic.dk).

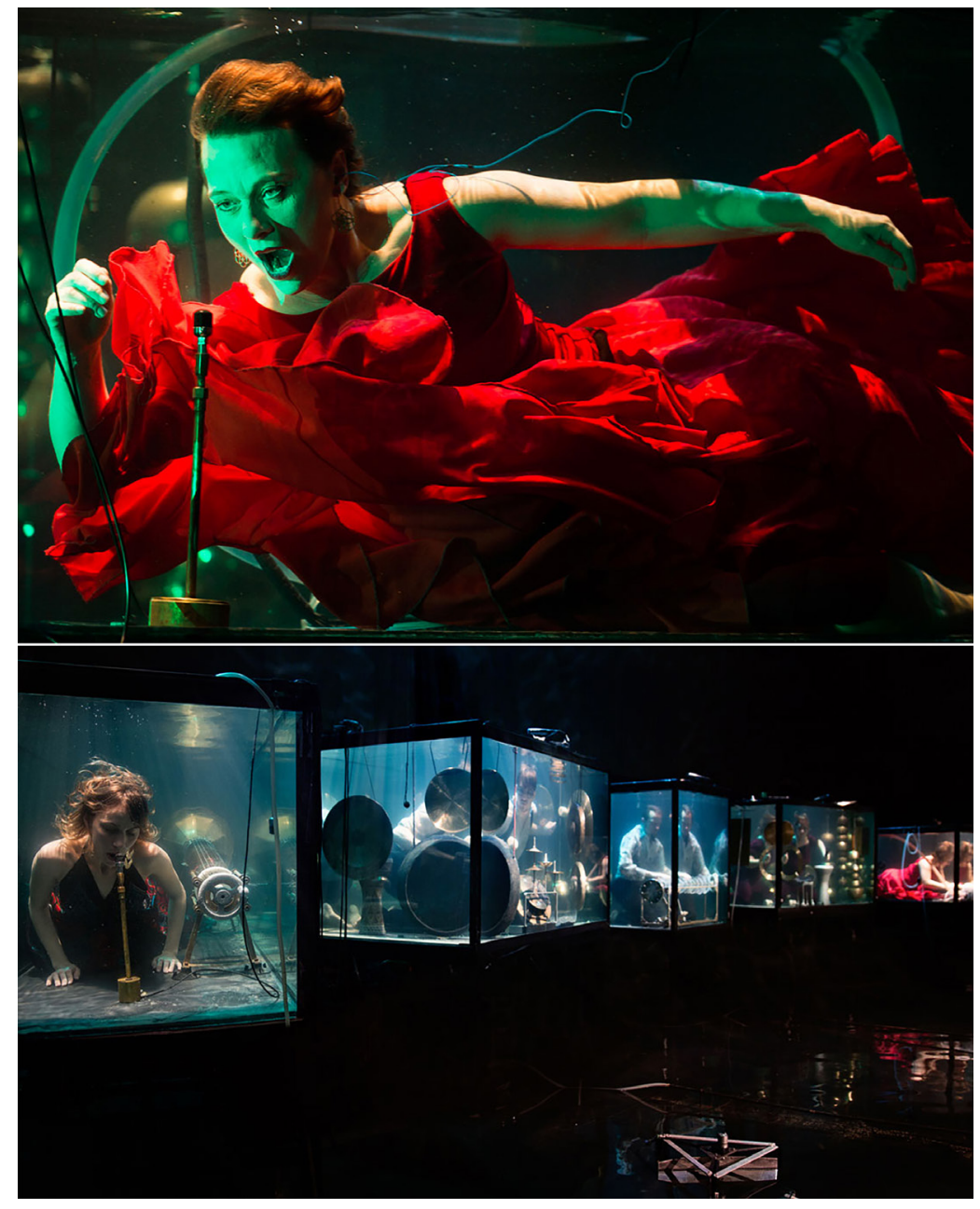

Note

[I] Gillo Dorfles, in Nuovi riti nuovi miti, usa il termine iconosfera coniato nel 1965 per indicare una efficace simbolizzazione antica che ebbero un tempo i miti.

[2] Fretum Siculum, termine latino che indica lo Stretto che congiunge due mari, ionico e tirrenico.

[3] Fausto Melotti, in Linee, stabilisce una capacità inconsueta di far respirare il vuoto dietro e tra le linee.

[4] In Penelope, si rappresenta trama e ordito dell'infinito tessere al telaio in attesa di un arrivo, nodi sciolti e ricomposti in una tela per causa di interminabile errare e ricongiungere.

[5] In Arianna, si rappresenta la consegna di un gomitolo di filo dato a Teseo, da dipanare nel labirinto di Cnosso, per evitare un macabro tributo al Minotauro.

[6] II transito tra due porti segue un consueto distacco da un punto all'altro, come appare nella poetica di un dipinto di Gauguin del 1890, il cui parallelo immaginario tra la rotta e il viaggatore appare come un colpo di rinterzo, tra l'indifferenza di Madame Ginoux, sulla biglia di un biliardo.

[7] Al contorno del logo si associa la figura di un insetto coleottero, la cetonia dorata o cetonia aurata che il medico naturalista Carlo Linnèo (| 707-1778) denomina scientificamente il coleottero come Melolontha.

[8] In Le Nuvole il commediografo greco Aristofane, rappresentata nel 423 a.C., vi è un riferimento a questo insetto, dove la fantasia viene accomunata ad una cetonia che il fanciullo lega facendola fremere nell'aria.

[9] Jan Fabre, in un percorso nomadico, realizza alcune opere con gusci di scarabeo, definendo una "metamorfosi di segni che cambiano come gli insetti, come un flusso e riflusso del mare".

[I0] <https://www.emozionearte.net/post/post/creta-minoica-e-il-culto-della-dea-madre-la-dea-dei-serpenti-di-cnosso>.

[I I] Le sirene conosciute con il nome di Leucosia, Ligea e Partenope, note pure come Aglaofeme, Molpe e Telsiepea, sono descritte da Omero, nel libro XII, versi 39 - 46. La narrazione le pone su un'isola presso Scilla e Cariddi e descrive la resistenza di Odisseo nello scendere dalla nave e la sorte delle sirene. Per Apollodoro formavano una triade di musicanti, rispettivamente, abili nell'uso della lira, del flauto e del canto. 
[12] Georges Simenon, attraversando lo Stretto di Messina a bordo di una goletta, descrive il passaggio tra Scilla e Cariddi e osservando annota: "da una parte c'è la Sicilia, con una città tutta bianca e l'Etna sullo sfondo del cielo. Dall'altra parte c'è la Calabria. Ma è soprattutto - ed è sempre stato - il confine tra due mondi". II resoconto del viaggio è pubblicato, tra giugnosettembre del 1934, sul settimanale francese Marianne.

[13] Roberta Joan Anderson, alias Joni Mitchell, considera l'album Blue del 197I come un diario di viaggio durante un periodo europeo. La frase appartiene a una traccia posta tra pensieri e gli appunti di un taccuino.

[14] <https://www.avvenire.it/agora/pagine/borges-ficciones-funes-memoria-neuroscienze>

[15] <https://phd.uniroma I.it/dottorati/cartellaDocumentiWeb/d33ceb69-2024-476b-b474-d52574al e5da.jpg>.

[16] Musubi significa nodo in giapponese, diviene elemento di annodamento per sistemi più complessi.

[I 7] Tanaka Ikko elabora alcuni poster ideografici, tra il nodo e l'intreccio, con il carattere di una comunicazione implicante.

[18] InsOut of a live communication project documenta l'esperienza di un workshop per lo studio di un brand per le isole Eolie.

[19] David Shrigley, artista visivo, fa parte di una generazione legata al movimento che si riconosce nell'anti-arte post-romantica. Nel 2005 ha realizzato la mappa per la metropolitana di Londra.

[20] Guns N' Roses, gruppo formatosi a L.A. nel 1985, su un genere cult, sono ideologia, irriverenza e immagine trasgressiva sulla scena musicale. La copertina dell'album rammenta il sistema di uno strano groviglio.

[2I] II logo ha una valenza propositiva per aprire un rapporto costruttivo verso la Casa dell'Architettura della città metropolitana di Reggio Calabria.

[22] <https://www.doppiozero.com/rubriche/4 I77/20 I708/leopardi-frammenti-di-una-cosmologia-poetica>.

[23] Ruth Asawa, artista americano, 1926 - 2013, la sua tecnica scultorea in filo somiglia a delle astratte tessiture. L'apprendimento acquisito in origine proviene da una tecnica usata a Toluca, in Messico, per fare cestini di filo zincato.

[24] Kue King, artista filippino - 198I, considera l'uso del filo coordinato con gli oggetti della natura, configurando forme e figure organiche.

[25] Chiharu Shiota, artista giapponese (1972), che con l'utilizzo di materiali tessili e altri oggetti, esprime concetti astratti di memoria, movimento, sogno e temporalità.

[26] La frase tratta da un testo di Cécile Corbel per una produzione sonora di carattere orientale.

[27] <http://astrocultura.uai.it/mitologia/antiche/ceneus.htm>.

[28] <http://astrocultura.uai.it/mitologia/antiche/ceneus.htm>.

\section{Riferimenti bibliografici}

AA.W. (2008). In Sout of a Live Communication Project. Milano: Lupetti - Editori di Comunicazione, p. I 7.

Avella Natalie (2005). Graphic Japan dalla xilografia allo zen dai manga al kawai, Logos. Modena, pp. I24-I25.

Calza Gian Carlo (a cura di). (1997). Tanaka Ikko. La grafica del Giappone. Milano: Electa, pp. 53-55.

Dorfles Gillo (2003). Nuovi riti nuovi miti. Milano: Skira.

Falsetti Marco (2017). Annodamenti. La specializzazione dei tessuti urbani nel processo formativo e nel progetto. Milano: FrancoAngeli.

Fiz A., Smith D. (a cura di). (2005). Intersezioni. Crag, Fabre, Paladino al Parco di Scolacium. Milano: Electa, pp. I | 4 - I I 7.

Melotti Fausto (2016). Linee. Milano: Adelphi Edizioni, p. 37.

Simenon George (2019). II Mediterraneo in barca. Milano: Adelphi, p. 98.

\section{Autore}

Rosario Giovanni Brandolino, Università degli Studi Mediterranea di Reggio Calabria, rgbrandolino@gmail.com

Per citare questo capitolo: Brandolino Rosario Giovanni (2020). Terraforma. Un musubi per lo Stretto disegnato/Terraforma. A musubi for the design of the Strait. In Arena A., Arena M., Brandolino R.G., Colistra D., Ginex G., Mediati D., Nucifora S., Raffa P. (a cura di). Connettere. Un disegno per annodare e tessere. Atti del $42^{\circ}$ Convegno Internazionale dei Docenti delle Discipline della Rappresentazione/Connecting. Drawing for weaving relationships. Proceedings of the 42th International Conference of Representation Disciplines Teachers. Milano: FrancoAngeli, pp. 3005-3024. 


\section{Terraforma. A Musubi for the Design of the Strait}

Rosario Giovanni Brandolino

\section{Abstract}

The subject matter of this project describes the process of elaboration and the similarities of the expressions of a brandmark dealing with the extension complexity of the image, which can be seen as an immaterial sign of a collection of derivative data and a kind of description including forms, texts, and noises of a global dimension.

It also establishes a concise declaration of connection, focusing on the adaptation of the elements of oriental tradition which, like a mosaic, combines the modernity of the Mediterranean and the antiquity of the Lands of the Orient.

Keywords

brandmark, drawing, image, knot, Stait.

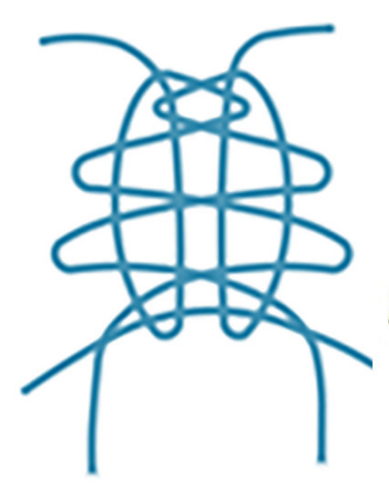

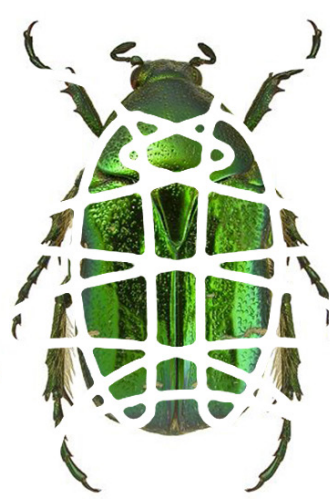

3015

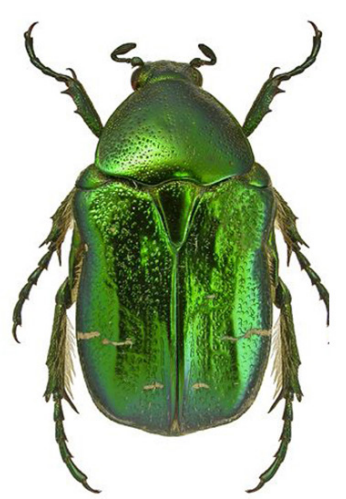

doi.org// 0.3280/oa-548.165 
Drawing is a form of meditation that forces you to pay attention. That's the primary aim of making art"' [Milton Glaser, graphic and illustrator]

Fig. I. Musubi.

The ideogram of the term musubi

or 結, is composed of the two term ito 糸,

meaning 'thread' and yoshi 吉, mening 'hapness'. the musubi binds two entities and represents the link with nature.
Fig. 2. Study notes, knot between connection and identity.
The brandmark is the key element of the connection between the image and the synthesis of its aspect, which is characterised by simplicity, recognisability and immediacy. This connection is a double union between iconospheres [I] and visual identity.

The resulting idea is an abstract concept, something fixed in an instant which identifies with the aquatic memory of remembering nothing, remembering something or remembering everything. It is a combination of signs which are reflected in the wavy furrow of a watershed separating the Fretum Siculum [2] in a floating order.

Considering the references, in the conceptual abstraction there is a transformation of the image into a reflection that connects different visions, where the liquid valley includes both the route created by the foam lifting a branch and the furrow of the route created by a helix following the movement of water.
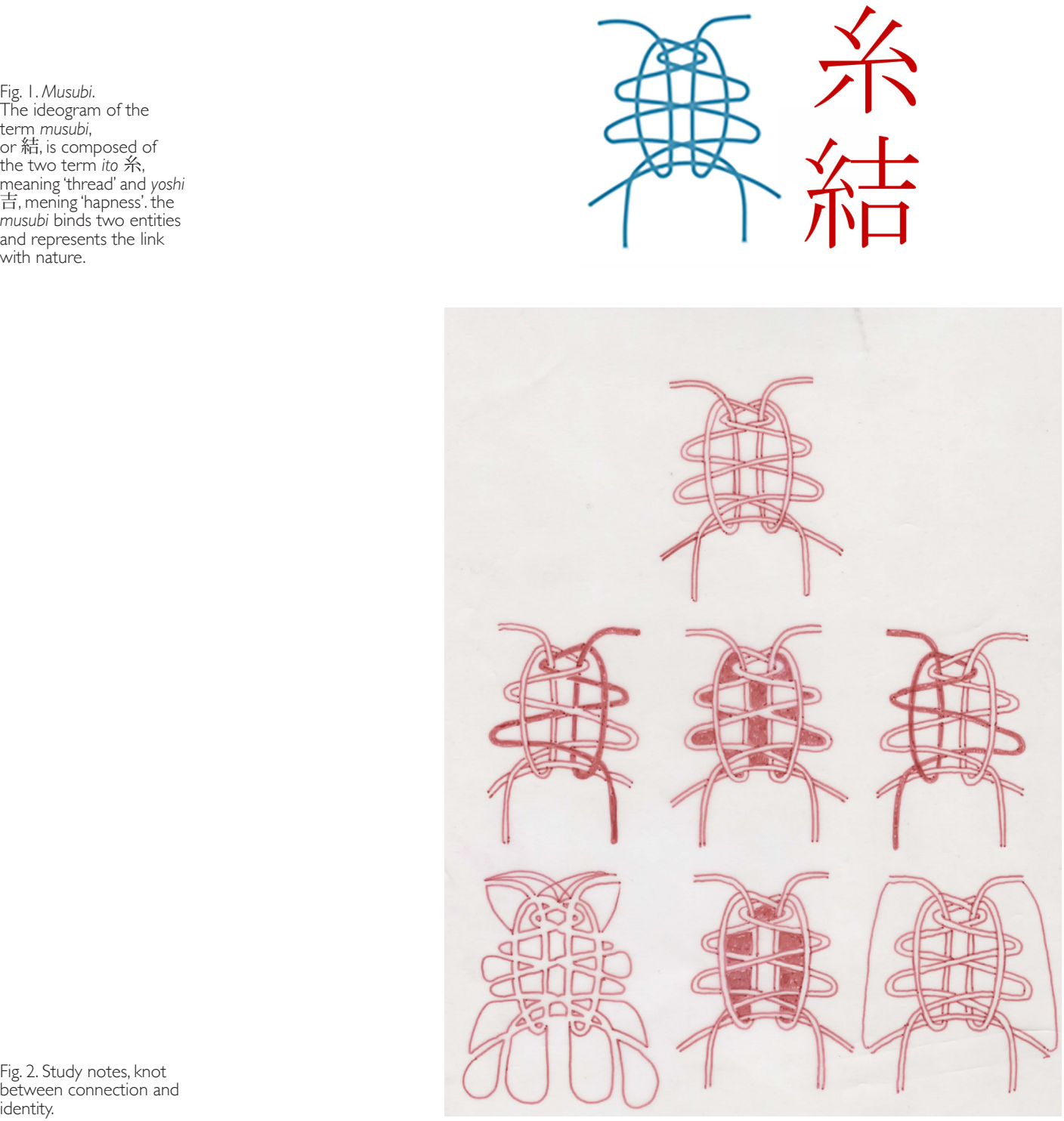
Fig. 3. Plots of writing and concept.
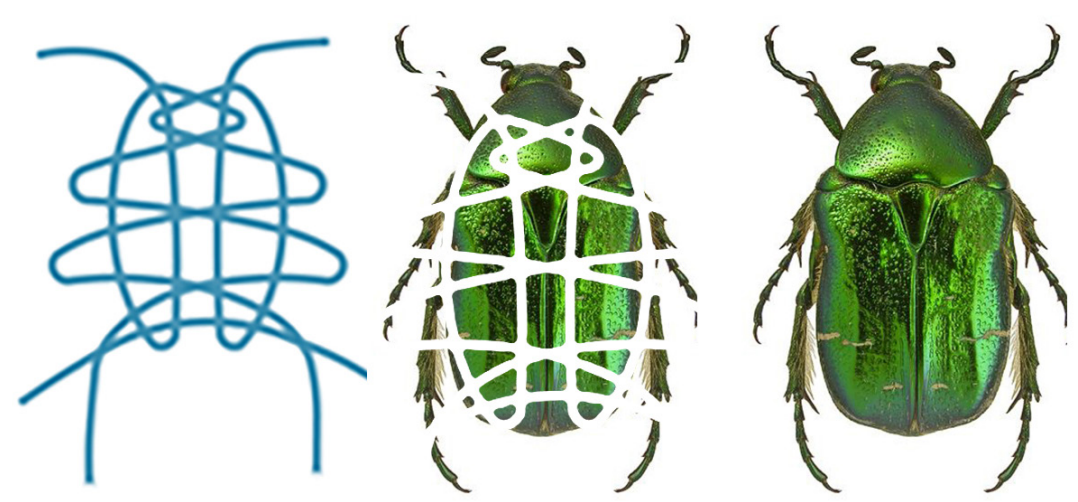

The image avails itself of an abstract interpretation in which the sign of a momentary passage is built through hydrodynamic implications, where the mark of the liquid footprints left by an undulating motion ends with the obsession of realising something that does not exist, a fluid channel among the thresholds of a veiled paradox.

"From the land we stare at the sea with dreamy eyes and when we are at sea we stare at the land like in a dream": this double assonance by Fausto Melotti [3] reveals the tendency of our mind to wander like a sail blown by the wind.

A root between two lands which includes reflections, memories and formal considerations and allows the emptiness to breath between the seduction of memory and the corruption of feelings.

The continuous and invisible tension of the rotation finds its sign in an ideal and stable vision through the navigation.

This symbolic representation consists of going beyond the elements of a circular rotating system, a mechanic movement that goes from port to port and from region to region.

The emerging element is a transition between two thresholds of the mainland which scratches the surface with lines originating from a usual itinerary.

A fluid space that turns into a composition of signs, which offer the possibility of organising information and conveying meanings.

The view of the Strait, between 'bastards', 'garofali' and 'oil stains', establishes a transit relationship which omits the invisible signs of continuous flows and moorings on water lines.

These connections, which are established between waterways and acoustic orders, represent an indefinite communication of interferences among the navigation trails and on-board signs.
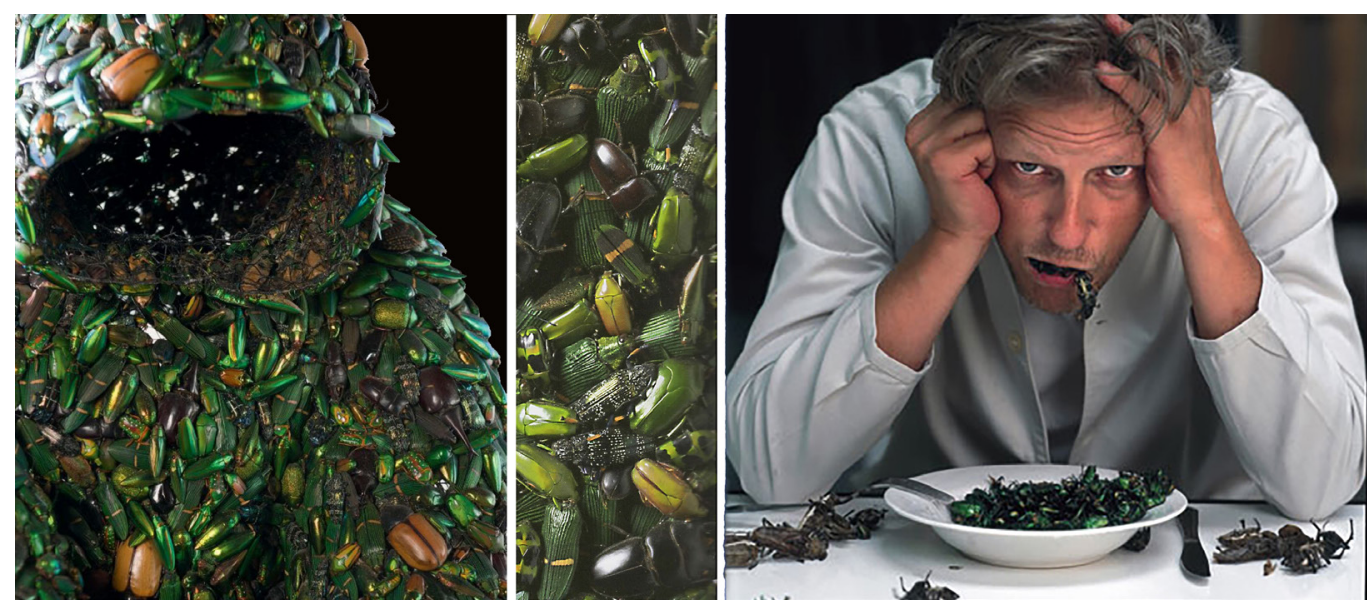
Fig. 5. Nicola Tripodi, Penelope e il filo di Arianna, 2019

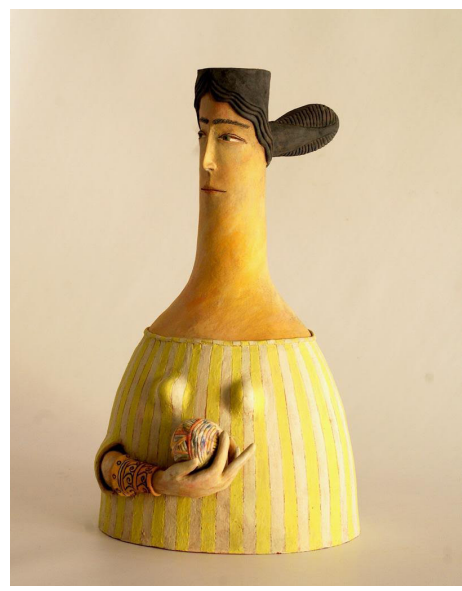

The following idea is a sign that appears on the path of a thread, a Greek energy made of lines and textures of a female myth, which evokes an immaterial connection between Penelope's shroud [4] and Ariadne's thread [5] for an apparent transition of navigation between connections and actions.

Among double senses, ambiguities and multiple interpretations there is a connection related to the continuity of a perception which reveals the strategy used by Ariadne to help Theseus escape from the Labyrinth built by Dedalus.

"Let Theseus come to our Labyrinth without being afraid of the Minotaur because Ariadne's thread will be the surest guide he could ever imagine, without which all his efforts will be a vain hope"

On the contrary, Penelope's shroud underlines the weaving of an interminable waiting for the return of Odysseus among the distances and the absolute coordinates expressed on the basis of a textile structure of an endless vision.

"She set up in her halls a great web, and fell to weaving fine of thread was the web and very wide.

Then day by day she would weave at the great web,

but by night would unravel it, when she had let place torches by her"

The design of the brandmark indicates the abstraction of a place, a component of an embroidery among the banks, an emerging warping which follows the formation of a carom like a marble rotating on a smooth surface [6].

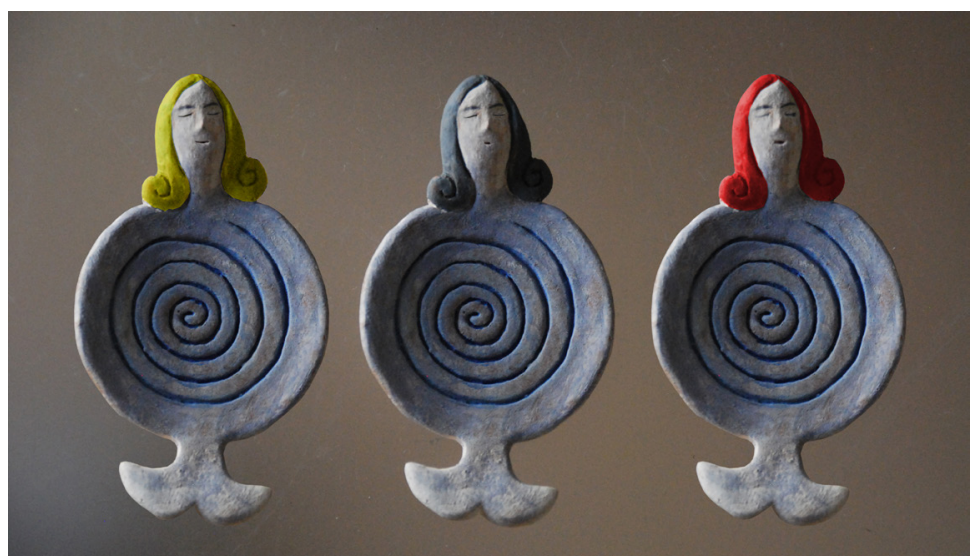


Other interpretations of the outline are traced in the shape of the cetonia aurata [7]. The shape of this insect can also be found in Aristophanes'The clouds [8] and Jan Fabre's works [9]. It is related to the variable elasticity of the stay, a particular way of tying used to wrap a cloth around the breast, as we can notice in a Cretan representation of the Snake goddess dating from 2000 a. C. [10].

Signs of luck or allusive elasticity represent the variation of distances of the invisible Mediterranean in order to create a circular dialogue about urban diversity in the Strait.

They are also metaphors of a balance hidden in the deceptive charm of the sirens [ I I]. A reference to the Area of the Strait, where dreamlike connections are written on the water lines narrated by Homer to Stefano D'Arrigo over time.

But, as Georges Simenon says: "Unlike Greece, the Mediterranean, located beyond the city of Messina, is something different; it is the symbol of the Eastern world..." [12]. This is what we perceive in the design of Musubi.

The Musubi knot used for the design of the Strait hides a suggestion in a verse by Roberta Joan Anderson: "Here is a shell for you. Inside you'll hear a sigh..." [I3].

Probably, the suggestion of this verse indicates a dialogue within an invisible tangle.

Remake, escamotage and allusion are parameters required to give the image a sign which contains a transition code between the physical appearance and its soul considering the observed directions.

Following the movement of a continuous Mediterranean, the description of flows, coasts, sea bottoms, tides, signals and winds reveals invisible trajectories and temporary trails located on a liquid surface of an uncertain, allusive and immaterial navigation.

In Fictions, published in 1944, Jorge Luis Borges described the lack of logic as the inability of conceptualising which leads to the Memorious. So, creating a similar sign for a floating identity leads to the need to create a singular system: "Funes not only remembered every leaf on every tree of every wood, but even every one of the times he had perceived or imagined it" [14].

Fig. 7. Tanaka lkko, Kamigatagei no kai, 1973 (The meeting of the arts of Kamigata). Poster for the show.

Fig. 8. Tanaka Ikko, Music today ' $80,1980$. Poster for the show.

Fig. 9. Tanaka lkko, Music today ' 85,1985 Poster for the show.
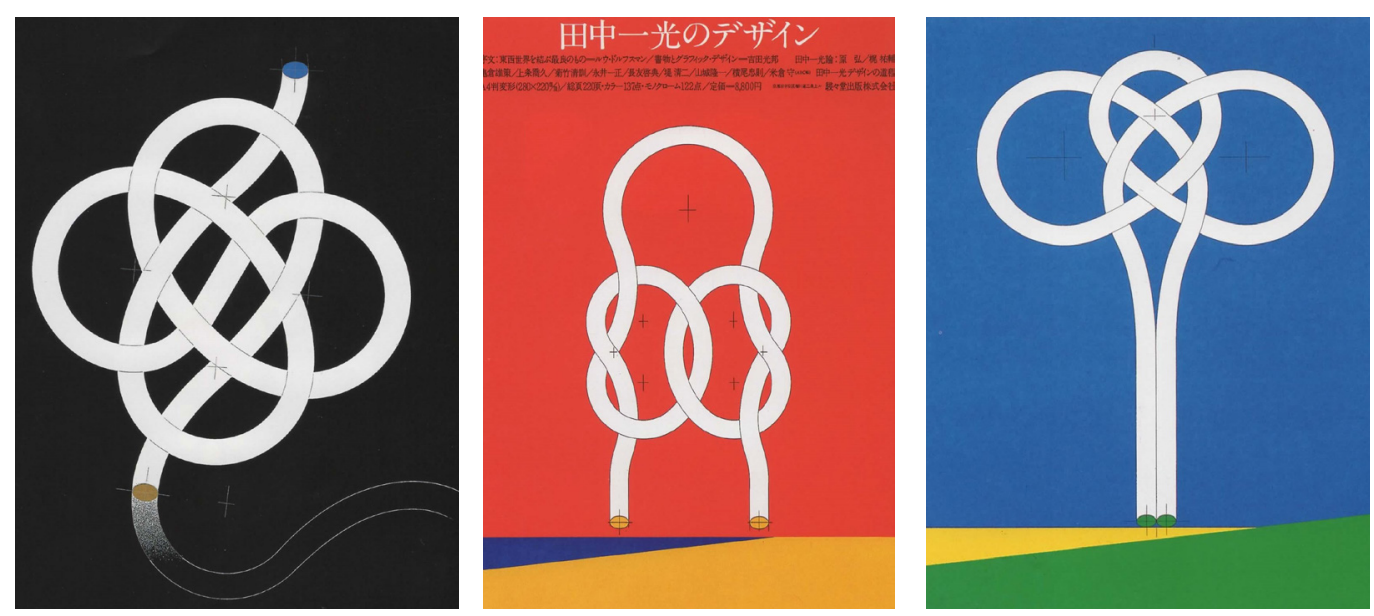

The graphic element represents a way of summing up tensions of belonging by connecting them with places. The image given by the Strait, between the island and the peninsula, describes the flowing of navigation on a directional sequence through opposing shipping lines. The design of 'Terraforma' contains the memory of a crossing in a flood. This concept refers to an analogy that, in an ancient Japanese painting, depicts the model of a Musubi knot. 
In the Japanese language we can distinguish four different types of knots according to their shape:

- musubi, which describes the connection;

- yubi, which represents the bond;

- me, which reproduces a closed empty space;

- shime, which indicates the conclusion.

This complexity is connected with the importance of knots in Japanese culture [I5].

Musubi is the old way of calling the local guardian god... This word has profound meaning. "Typing thread is Musubi.

Connecting people is Musubi.

The flow of time is Musubi.

These are all the god's power. So, the braided cords that we make are the god's art and represent the flow of time itself.

They converge and take shape. They twist, tangle, sometimes unravel, break, and then connect again. Musubi-knotting. That's time" [16].

Other considerations about tying knots are visible in Ikko Tanaka's creations [17], where the knots are like images, interrelations, stylistic features, testimonies of a floating world and signs of the unnecessary in the art of simplification.

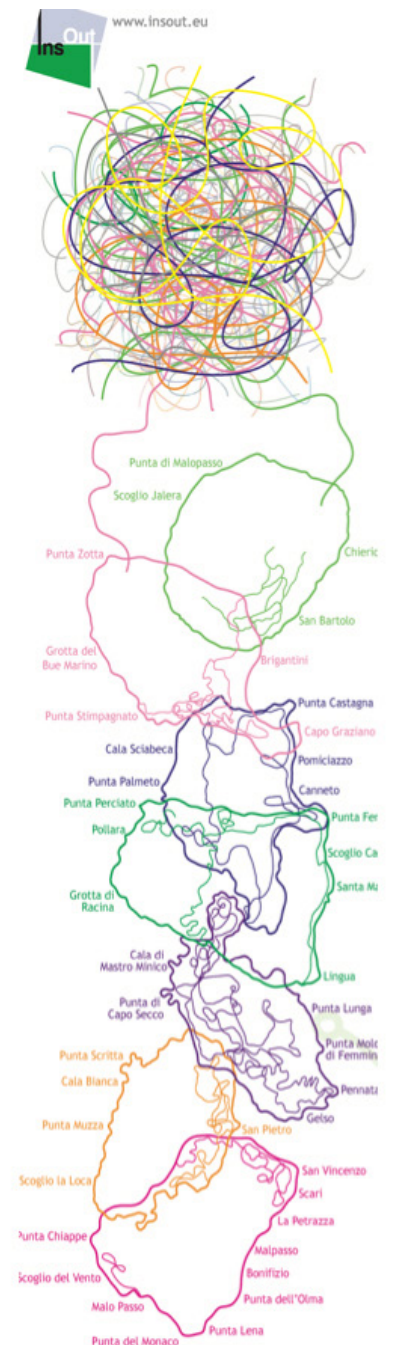

Fig. 10. Rosario Giovann Brandolino, OutSea/InSec poster "... dalla metro all'arcipelago", da un'idea di D. Shrigley, 2005.

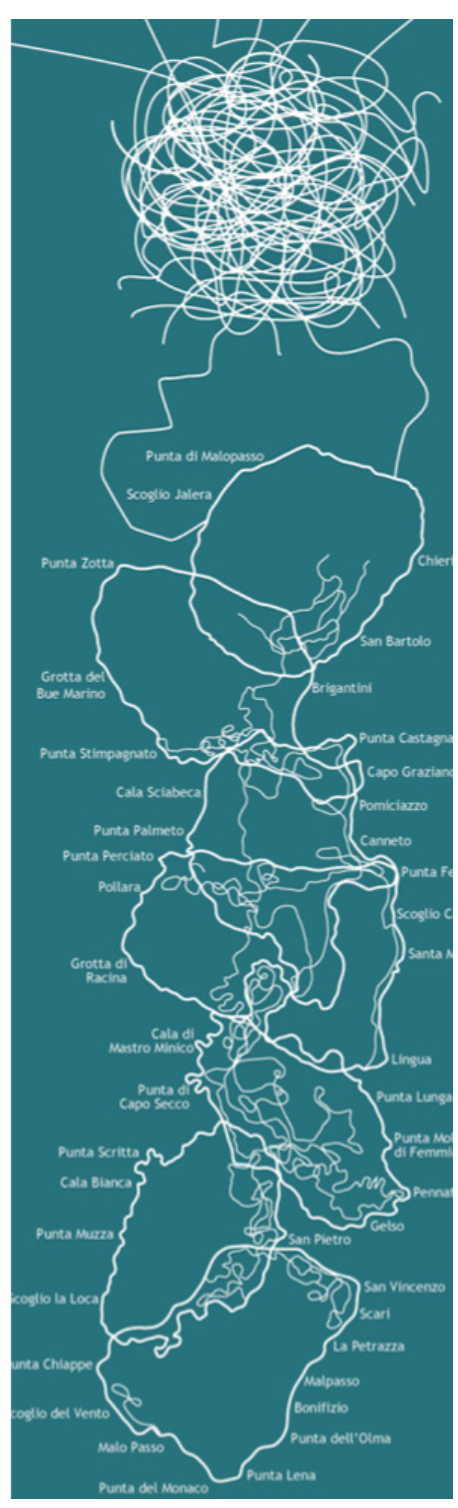


"The real creativity is illegal, not in the criminal sense, but in the way that a poet creates an intellectual revolution" Philippe Petit, high-wire artist

We can find other drawing lines in different experiences with similar analogies, a contemplative backwash and a formal sense which implies considerations about compositions in different spheres for a concept of synthesis.

A lack of communication in different experiences represents an interesting repetition and a program of integrated communication of the archipelago of the Aeolian Islands [18].

The spindly brandmark proposes a critical consideration with the aim to promote the image of a creative workshop between the Mediterranean University of Reggio Calabria and the London College of Communication for a branding of the seven islands.

This branding regards the extension of a spindly shape which defines a relevant 'coexist' of a trans-hypogeum habitat, a panoramic path concerning the iconic London tube map drawn by David Shrigley [19] in 2006 and the projection of a 'brisè' on the water lands in the Aeolian Islands.

The mixtures used to interpret the context in the vision of a language, between an organic magic and a dreamlike magic, take into consideration coloured lines and use them like a simple chaotic scrawl.

The dimension belonging to the observer's intuition is developed in an image suggested by Guns N'Roses [20] in their album The Spaghetti Incident?, recorded in 1993, which is part of the figurative connection of a photography.

It is possible to notice other hanging threads in the brandmark ofThe House of Architecture in the Metropolitan City of Reggio Calabria [2 I], designed in collaboration with the city of Porto. The brand image originates from a fragment of Giacomo Leopardi's Zibaldone (256, October Ist 1820), which, after the two-hundredth anniversary of its publication, is still able to create a philosophical and philological thought which turns into image, content and form. "The construction of a hanging space is like a house hanging in the air held by ropes to a star" [22]: with this similitude, Leopardi affirms that houses contain stories and stories contain parallel universes.

The construction related to the perceptive ambiguities of art can be traced in the quotation from Ruth Asawa [23]: "The economy of a line makes something in space, enclosing it without blocking it out". Other contemporary artists who works with wire are Kue King [24], who sculpts wire using a woven additive technique, and Chiharu Shiota [25], who expresses the connection with nature in her installations made of thousands of threads.
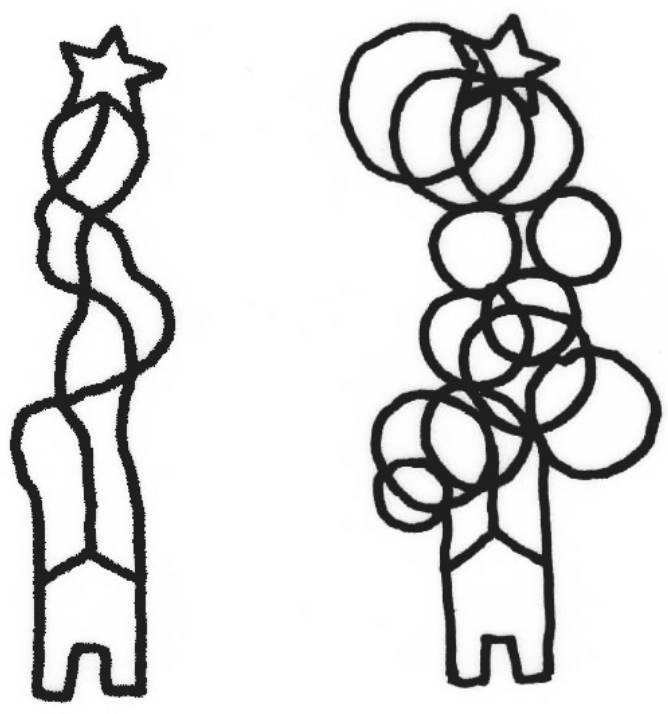

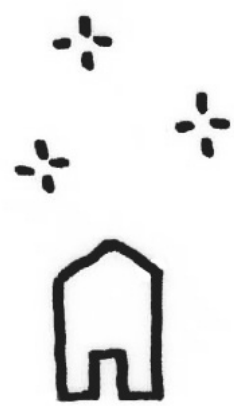



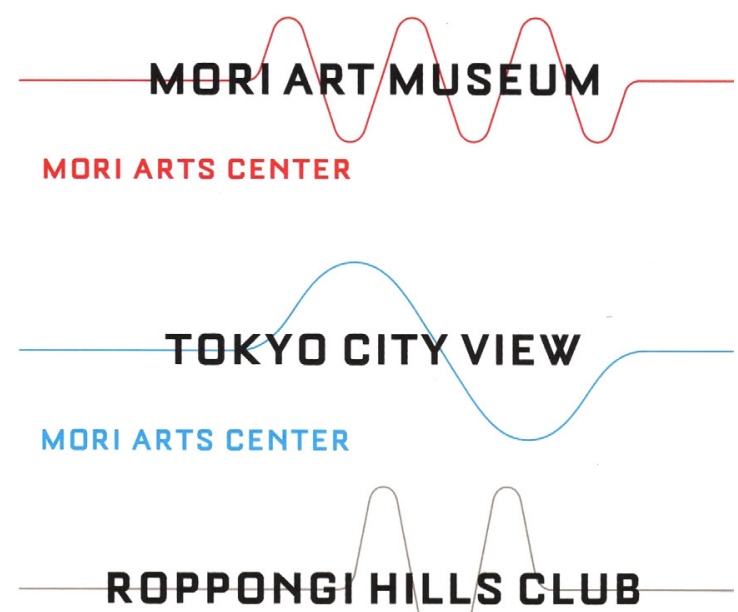

Fig. 12. Johnatan

Barnbrook e Associati

Mori Arts Centre - MAM,

corporate identity, Tokyo 2013

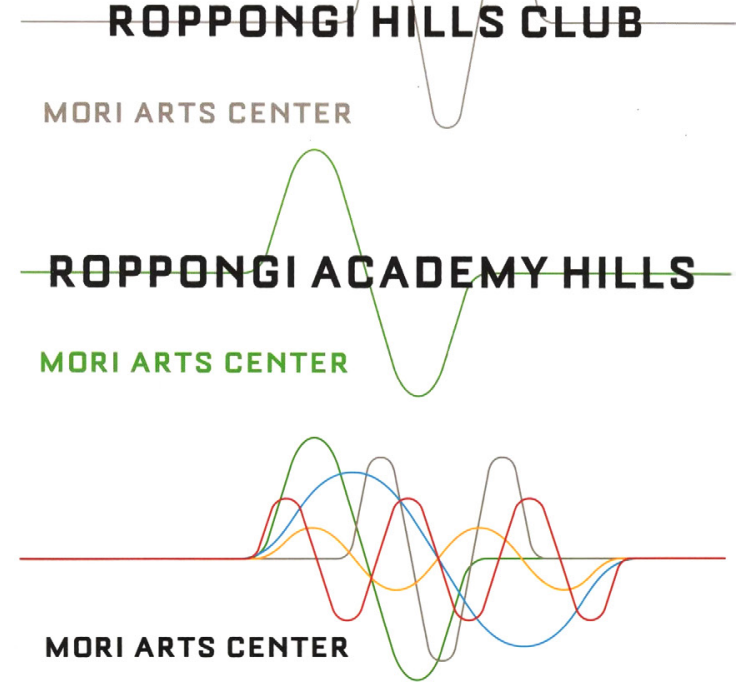

The brandmark realised for Connettere is a drawing designed to tie and weave knots, a design which defines an intersection of different influences in order to reconstruct a corporate identity for the Strait. It is a tangle of linear forms which represents the topos of the double, two autonomous lines of distinct entities in the intersection of a collection of knots crossing two seas.

A secret world under the liquid floor [26] which, inspired by the mythologic figure Caeneus (Kaineús in ancient Greek), reconstructs the octagonal axis of a morphology which is submerged between the two seas.

The myth of Caeneus [27] contains a changeable similitude which expresses a mutual crossing appearing in the body shape [28] and in the transformation into a nymph.

The brandmark symbolises the connection situated on the lines of a path among the slopes of a Mediterranean space, between the Bosporus Canal and the Strait of Gibraltar and the distance between two lands.

The expression of the brandmark 'Terraforma' contains the interpretation of a formal aspect whose predecessors are David Shrigley, who designed the London tube map in 2006, Jonathan Barnbrook, who designed the Mori Artis Center in Tokyo in 2004, and the double tangle of an ancient Japanese Musabi knot, which represents a bijective trend of sailors in a floating connection under a tired sky. (Translated by Martina Fazzari - 5.2020). 
Fig. 13. AquaSonic, a Danish "seapunk" band fuses singing and chamber music to produce a dreamlike performance on a liquid space. Laila Skovmand, like a mermaid, expresses a captivating song. (Credit images: Ph. song. (Credit images: Ph. JamieSimpson@ Heral and TImes Group / Ph. Charlotta De Miranda in https://style.corriere. it/... Aquasonic - w
betweenmusic.dk).

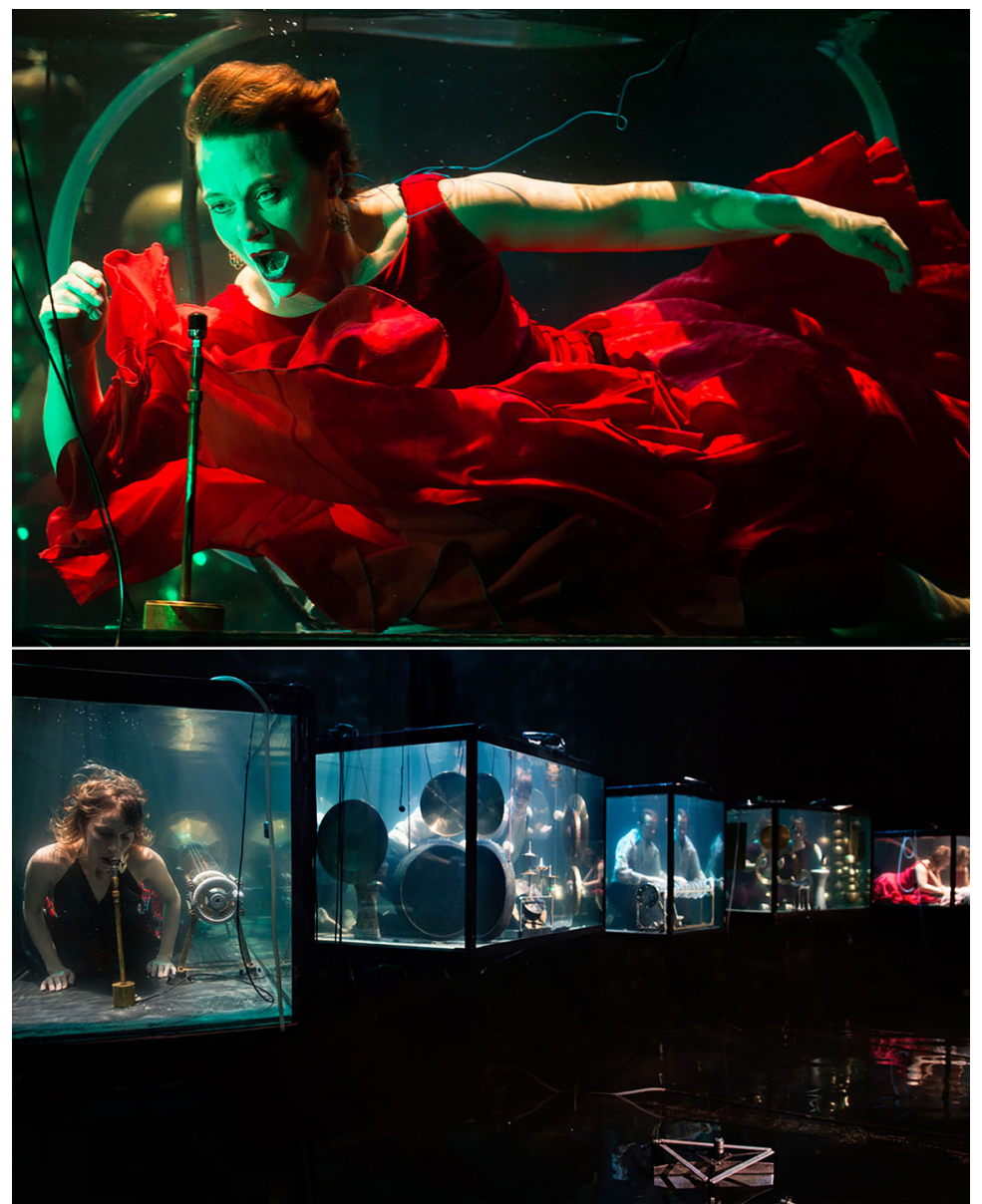

Notes

[I] Gillo Dorfles uses the term iconosphere, which was coined in 1965, in his book New rituals, new myths to indicate the effective symbolisation of ancient myths.

[2] Fretum Siculum is a Latin term used to refer to the Strait which joins the lonian Sea with the Tyrrhenian Sea.

[3] Fausto Melotti establishes the existence of an unusual ability which allows the emptiness to breath behind and among the lines in his book Linee.

[4] The myth of Penelope describes a process of dissolution and reassembly through a combination of warp and weft and focuses on Penelope's endless weaving and unweaving of a burial shroud for Laertes, father of Odysseus, waiting for the return of her husband.

[5] The myth of Ariadne tells the story of Ariadne who gives his lover Theseus a ball of thread to escape from the Labyrinth situated in the Palace of Knossos and end the macabre tribute to the Minotaur.

[6] The passage between two ports implies a separation between two points, which is depicted in Night Café at Arles, a poetic painting executed by Gaugin in 1890, where the imaginary parallel between the root and the traveller is compared to a billiards shot.

[7] The outline of the brandmark is associated with the shape of a beetle called cetonia aurata, also known as the rose chafer. Carolus Linnaeus (1707-1778), Swedish doctor and naturalist, used the scientific name Scarabaeus Melolontha to indicate this beetle species.

[8] In his comedy play Clouds, performed in 423 a. C., Aristophanes, the most important comic playwright of ancient Greece compared phantasy with a beetle flying through the air.

[9] During his nomadic existence Jan Fabre, Belgian artist and playwright, has created monumental sculptures made from beetle shells, in which he compares the transformation of his art with the metamorphosis of insects which constantly change like a flow of water.

[I 0] <https://www.emozionearte.net/post/post/creta-minoica-e-il-culto-della-dea-madre-la-dea-dei-serpenti-di-cnosso>.

[I I The sirens, known by the names of Leucosia, Ligea and Partenope or also known as Aglaofeme, Molfe and Telsiepea, are described by Homer in the Book XII, lines 39-46. According to the narration, which describes Homer's resistance while leaving the ship and the sirens' fate, the sirens live on an island between Scylla and Charybdis. According to Apollodorus, they formed a triad of musicians who where, respectively, skilled in the use of the lyre, the flute and singing. 
[12] While passing through the Strait of Messina aboard schooner, Georges Simenon, Belgian-French novelist, described the passage between Scilla and Cariddi as follows: "On one side there is Sicily, with its white sands and Mount Etna in the background, on the other side there is Calabria. But it is all about the border between two worlds". The travel report was published in the period between June and September 1934 on the French news magazine Marianne.

[13] Roberta Joan Anderson, alias Joni Mitchell, considers her album Blue like a travel journal about her experience in Europe. This phrase is taken from the homonymous track written down in a notebook along with her thoughts and notes.

[14] <https://www.avvenire.it/agora/pagine/borges-ficciones-funes-memoria-neuroscienze>.

[15] <https://phd.uniroma I.it/dottorati/cartellaDocumentiWeb/d33ceb69-2024-476b-b474-d52574al e5da.jpg>.

[16] The Japanese term Musubi means knot and refers to a complex system of knotting.

[ I7] Tanaka Ikko realizes some hydrographic posters with the aim to create a captivating communication between the knot and the tangle.

[18] InsOut of a live communication project documents a workshop experience realized to create a brandmark for the Aeolian Islands.

[19] David Shrigley, British visual artist, belongs to a generation which identifies in the postromantic Anti-art movement. He designed the map of the London Underground in 2005.

[20] Guns N' Roses is an American rock band formed in Los Angeles in 1985, which changed the rock music scene with it transgressive and irreverent songs. The album cover resembles a strange tangle of threads.

$[2 I]$ The brandmark has a positive significance and establishes a constructive relationship towards the House of Architecture of the Metropolitan City of Reggio Calabria.

[22] <https://www.doppiozero.com/rubriche/4 177/20 1708/leopardi-frammenti-di-una-cosmologia-poetica>.

[23] Ruth Asawa (1926 - 2013), American artist and sculptor, creates tied-wire sculptures which resembles abstracts textures. Her wire weaving method draws inspiration from a technique used in Toluca, in Mexico, to wave baskets made of galvanized steel.

[24] Kue King (198I-), Filipino American sculptor, creates abstract and geometric sculptures combining the use of wire tightly fastened to objects of nature to create organic forms and figures.

[25] Chiharu Shiota (1972-), Japanese installation artist, uses textile materials and other object to express the abstract concepts of memory, movement, dream and temporality.

[26] The phrase is taken from a song by Cécile Corbel, French singer and harpist, who is able to create an oriental atmosphere with her music.

[27] <http://astrocultura.uai.it/mitologia/antiche/ceneus.htm>.

[28] <http://astrocultura.uai.it/mitologia/antiche/ceneus.htm>.

\section{References}

AA.W. (2008). In Sout of a Live Communication Project. Milano: Lupetti - Editori di Comunicazione, p. 17.

Avella Natalie (2005). Graphic Japan dalla xilografia allo zen dai manga al kawai, Logos. Modena , pp. I24- 125.

Calza Gian Carlo (a cura di). (1997). Tanaka Ikko. La grafica del Giappone. Milano: Electa, pp. 53-55.

Dorfles Gillo (2003). Nuovi riti nuovi miti. Milano: Skira.

Falsetti Marco (2017). Annodamenti. La specializzazione dei tessuti urbani nel processo formativo e nel progetto. Milano: FrancoAngeli.

Fiz A., Smith D. (a cura di). (2005). Intersezioni. Crag, Fabre, Paladino al Parco di Scolacium. Milano: Electa, pp. I I 4 - I 17.

Melotti Fausto (2016). Linee. Milano: Adelphi Edizioni, p. 37.

Simenon George (2019). II Mediterraneo in barca. Milano: Adelphi, p. 98

\section{Author}

Rosario Giovanni Brandolino, Università degli Studi Mediterranea di Reggio Calabria, rgbrandolino@gmail.com

To cite this chapter. Brandolino Rosario Giovanni (2020). Terraforma. Un musubi per lo Stretto disegnato/Terraforma. A musubi for the design of the Strait. In Arena A., Arena M., Brandolino R.G., Colistra D., Ginex G., Mediati D., Nucifora S., Raffa P. (a cura di). Connettere. Un disegno per annodare e tessere. Atti del $42^{\circ}$ Convegno Internazionale dei Docenti delle Discipline della Rappresentazione/Connecting. Drawing for weaving relationships. Proceedings of the 42th International Conference of Representation Disciplines Teachers. Milano: FrancoAngeli, pp. 3005-3024. 